\title{
ДО ПИТАННЯ ПРО РОЛЬ П. М. МІЛЮКОВА У ЛЮТНЕВІЙ РЕВОЛЮЦІї 1917 РОКУ В РОСІЇ
}

\author{
В. С. Золотарьов, Н. П. Олешко
}

Золотарьов В. С., Олешко Н. П. До питання про роль П. М. Мілюкова у Лютневій революції 1917 року в Росії. У статті йдеться про діяльність голови Конституційно-демократичної партії Росії та одного з лідерів ліберально-демократичного руху П. М. Мілюкова напередодні та під час Лютневої революції 1917 р. у Росії. Автори дослідили головні аспекти думської діяльності Мілюкова, визначив його роль у створенні Прогресивного блоку та Тимчасового комітету Державної Думи. Розглядається також участь Мілюкова у подіях 28 лютого 1917 р. щодо стабілізації ситуації у столиці серед військ Петроградського гарнізону та на посаді міністра закордонних справ Тимчасового уряду Росії.

Ключові слова: Конституційно-демократична партія; революція; Державна Дума; Тимчасовий уряд.

Золотарёв В. С., Олешко Н. П. К вопросу о роли П. М. Милюкова в Февральской революции 1917 года в России. В статье рассматривается деятельность главы Конституционно-демократической партии России и одного из лидеров либерально-демократического движения П. М. Милюкова накануне и во время Февральской революции 1917 г. в России. Авторы исследовали главные аспекты думской деятельности Милюкова, его роль в создании Прогрессивного блока и Временного комитета Государственной Думы. Рассмотрено также участие Милюкова в событиях 28 февраля 1917 г. по стабилизации революционной ситуации в столице среди войск Петроградского гарнизона и в должности министра иностранных дел Временного правительства.

Ключевые слова: Конституционно-демократическая партия; революция; Государственная Дума; Временное правительство.

Zolotarev V. S., Olesko N. P. On the Question of the Role of P. M. Milyukov in the February Revolution of 1917 in Russia. In this article it the activity of the head of the Constitutional-Democratic Party of Russia and one of the leaders of the liberal-democratic movement P. N. Milyukov on the eve of and during the February revolution 1917 in Russia is discussed. The authors investigated the main aspects of the Milyukov activities in Duma, his role in the creation of the Progressive Bloc and the Temporary Committee of the State Duma. Also, the participation of Milyukov in the events of February 26, 1917 on stabilizing the revolutionary situation in the capital among the troops of the Petrograd garrison and in the post of Minister of Foreign Affairs of the Temporary Government it is considered.

Keywords: the Constitutional-Democratic Party; the Revolution; the State Duma; the Temporary Government.

У лютому 2017 році відзначалося 100-річчя Лютневої революції в Росії, наслідками якої стали суттєві зміни як в Російській імперії, так і у світовій історії взагалі: повалення самодержавства в Росії, крах інших імперій, несподівані підсумки завершення Першої світової війни, кардинальні перетворення у політичному та соціально-економічному розвитку провідних країн світу. Важливі зміни відбулися і в Україні: було сформовано Українську Центральну Раду та почалася Українська національно-демократична революція. Розпочався шлях боротьби українського народу за створення власної держави.

Мета даної статті полягає в тому, щоб дослідити ставлення одного з лідерів ліберальної опозиції Росії та голови Конституційно-демократичної партії Павла Миколайовича Мілюкова до Лютневої революції 1917 року та з'ясувати його роль у той буремний час. Для цього слід розглянути еволюцію поглядів самого П. М. Мілюкова до революцій взагалі та його ставлення до подій лютого 1917 року.

За часів незалежності в Україні значно збільшився науковий інтерес до ліберального руху Росії та його провідної сили - Конституційно-демократичної партії (КДП). Перш за все це пояснюється тим, що саме КДП підняла важливі проблеми розвитку національних окраїн імперії, припускаючи навіть право націй на власну автономію. Така позиція сприяла добрим стосункам кадетів з українськими лібералами на чолі з М. С. Грушевським. Протя- 
гом 1912-1917 рр. між Грушевським та Мілюковим відбувається значна кількість як офіційних, так і неофіційних контактів. Багато спільного було між ними: обидва видатні історики, мали однакові проєвропейські ліберально-демократичні погляди, справжні інтелігенти. У Державному архіві Російської Федерації збереглася частина листування між ними ${ }^{1}$.

Кадети завжди залишалися еволюціоністами, що докорінно відрізняло їх від соціалдемократів. Один з лідерів та засновників кадетської партії П. Б. Струве ще 1906 р. писав: «...Еволюціонізм розуміє політику як виховання, революціонізм розуміє політику як примушення. Революціонізм заснований на ідеї, що в політиці вирішальним фактором $\epsilon$ змагання політичних сил, еволюціонізм заснований на ідеї, що таким фактором є духовне перевиховання людей» ${ }^{2}$. Це дуже важливий висновок, адже така точка зору дає уявлення про те, що моральний фактор кадети розглядали як найважливішу умову політичних перетворень, як альтернативу революційній боротьбі. Крім того, кадети своєрідно розглядали й сам процес розвитку демократії. П. Б. Струве стверджував: «...розвиток демократії є ланцюг компромісів, тому що сама демократія $\epsilon$, як влучно сказав Бернштейн, “вища школа компромісу", оскільки виховання $є$ не що інше, як система психологічних компромісів» ${ }^{3}$. Цей важливий методологічний принцип одного з теоретиків кадетської партії дозволяє говорити про те, що у своїх прагненнях до демократії кадети використовували відмінні від інших партій тактичні настанови. Для них шлях до демократії - насамперед виховання (розвиток правової культури суспільства) за допомогою системи компромісів. Цим положенням багато в чому й пояснюється прагнення кадетської партії до співробітництва як із трудовиками, так і з октябристами, навіть із урядом. Жодна інша політична партія не мала настільки широко політичного спектра співробітництва. У цьому її й заслуга, у цьому її й трагедія, адже вона так і не знайшла своєї широкої соціальної опори. Вплив П. Б. Струве на П. М. Мілюкова був досить значним, про що говорить створення програми КДП та стратегія і тактика кадетів під час першої революції 1905-1907 рр.

Восени 1916 р. всередині країни політичні умови продовжували ускладнюватися, а надій на реалізацію програми Прогресивного блоку" майже не залишалося. Активізувався революційний рух серед робітничого класу, на селі, в армії та на флоті. Активність пролетаріату викликала занепокоєння серед лібералів. 24 жовтня 1916 р. А. І. Шингарьов на засіданні бюро Прогресивного блоку так сформував нову політичну ситуацію в Росії: «Показати гірше того, що є, неможливо. Усередині країни починається голод. Місто напередодні неможливості придбати хліб. Робітники під впливом лівих, майже готові вийти на вулицю» ${ }^{4}$

За таких умов 1 листопада 1916 р. відкрилася сесія Думи. Відома ця сесія, перш за все, промовою П. М. Мілюкова, в якій він розкритикував військову та економічну неспроможність політики царського оточення й уряду. От що пізніше писав сам П. М. Мілюков із цього приводу: «...Я усвідомлював той ризик, якому піддавався, але вважав за необхідне 3 ним не рахуватися, тому що, дійсно, наступала “вирішальна година", я говорив про плітки про "зраду”, які нестримно поширюються по країні, про дії уряду, які збуджують громадське обурення, причому в кожному випадку надавав слухачам вирішити, “дурість це - чи зрада"? Аудиторія рішуче підтримала своїм схваленням друге тлумачення - навіть там, де сам я не був у ньому цілком впевнений ${ }^{5}$. Ця промова мала значний вплив на подальший розвиток революційної ситуації у Росії. Ї̈̈ нелегально було надруковано на гектографі й розповсюджено багатотисячними примірниками у країні та на фронті.

Становище в Російській імперії ставало все більш напруженим. Криза на початку 1917 р. охопила всі галузі економіки: промисловість, залізничний транспорт, сільське господарство. Взимку країна справді опинилася на грані голоду; у січні активізувався страйковий рух. За останні 3 місяці 1916 р. офіційними джерелами було зафіксовано 328 випадків припинення роботи на заводах і фабриках за участі 268 тис. промислових робітників, а в січні відбулося вже 400 страйків, з них 60\% було політичними. Страйкувало понад 270 тис. робітників

\footnotetext{
* Прогресивний блок було створено у серпні 1915 року представниками депутатських фракцій IV Державної Думи (кадети, октябристи, прогресисти, «прогресивні руські націоналісти») 3 метою створення уряду «народної довіри».
} 
П. М. Мілюков відчував наближення революції, про що свідчать його власні спогади: «7-13 лютого страйки в місті тривали, почалися зіткнення з поліцією. Слухи про виступи 14 лютого прийняли конкретну форму і за ними неважко було побачити поліцейську провокацію. Протопопов, напевно, готувався викликати "революцію" штучно й розстріляти іiі за зразком Москви 1905 р. Моє ім'я було названо як ім'я одного з підбурювачів до демонстрації робітників. Мені довелося написати звернення до робітників, в якому я закликав ïx не піддаватися на цю провокацію. Моє звернення викликало критику зліва, але мети воно своєї досягло: 14 лютого виступ робітників не відбувся» ${ }^{7}$. Все це говорить про те, що Мілюков був добре поінформованим про події у столиці імперії й сам перебував у центрі цих подій. Його «Звернення» від 9 лютого 1917 р. до робітників спростовує точку зору деяких радянських істориків, котрі стверджували, що вже у лютому ліберальна опозиція була неспроможною. «Ці люди не були спроможні ні до якої серйозної боротьби», - писав О. Я. Аврех про лідерів ліберальної опозиції, намагаючись довести, що «вести цю боротьбу вони не бажали» ${ }^{8}$. Є. Д. Черменський, аналізуючи методи й тактику кадетів у цей час, дійшов висновку: вони лише займалися «симуляцією опозиційної боротьби, а звинувачення на адресу уряду - як прикриття» ${ }^{9}$. Проте це не відповідає дійсності.

Політична ситуація у Петрограді в лютому 1917 р. швидко загострювалася. Початком Лютневої революції прийнято вважати події у столиці, які розгорнулися в міжнародний жіночий день 23 лютого 1917 р. Уряд виявився зовсім нездатним запобігти тим заворушенням, які почалися. І хоча створена урядом продовольча комісія зуміла своїми діями послабити ситуацію, пов'язану з перебоями в постачанні міста хлібом, запобігти революційним виступам народу вона була не в силах. Уряд почав обговорювати питання: розпустити Державну думу чи оголосити перерву в ії роботі? 3 метою порятунку свого становища та приборкання революції влада - міністр закордонних справ М. М. Покровський та міністр землеробства М. О. Ритих - пішла на переговори з лідерами Прогресивного блоку, в результаті яких отримали наступну відповідь: «Примирення неможливо, депутати вимагали зміни уряду та призначення нових міністрів з осіб, які користуються громадською довірою» ${ }^{10}$.

Уряд визнав ці вимоги неприйнятними, й у відповідь його голова Н. Д. Голіцин підписав указ про перерву у роботі Думи з 26 лютого. Позицію, яку зайняв Прогресивний блок (де кадети посіли провідні ролі), спростовує точку зору багатьох радянських істориків, котрі стверджували, що кадети в цей час прагнули до співробітництва 3 урядом 3 метою приборкати революцію та випросити у царя міністерські посади для своїх лідерів.

Головним для П. М. Мілюкова і його партії стало питання про формування нової влади. Ліві кадети підтримали пропозицію меншовиків і трудовиків про те, щоб Дума взяла на себе її організацію ${ }^{11}$. М. В. Некрасов (лідер лівих кадетів) переконував встановити військову диктатуру. На його думку, треба домагатися від уряду указу про передачу всієї повноти влади товаришу військовому міністру, начальнику Головного артилерійського управління генералу О. О. Маніковському. П. М. Мілюков відреагував миттєво і заявив, що старий уряд випустив владу зі своїх рук і вступати з ним у перемовини марно. Однак Думі проголошувати себе владою також не варто, оскільки законодавча установа брати на себе виконавчі функції не може. Відкидаючи план М. В. Некрасова, П. М. Мілюков радив зупинитися на реальному плані поділу влади між представниками династії й Думою ${ }^{12}$.

Авторитет П. М. Мілюкова виявився вагомим у цей критичний час. Було ухвалено його рішення про створення Тимчасового комітету членів Державної думи. Мета Комітету полягала у відновленні порядку та встановленні відносин з політичними лідерами й установами. До з'ясування обставин і прояснення ситуації «ця, формула, - зі слів П. М. Мілюкова, - мала ту перевагу, що задовольняла потребам часу та нічого не визначала надалі. Обмежуючись мінімумом, вона все-таки створювала новий орган і не підводила думців під кримінал» ${ }^{13}$.

Необхідно підкреслити, що в умовах революції партію кадетів уже не задовольняла стара форма стосунків з урядом. Навіть при певних умовах iï все одно б тримали на відстані від державної влади. А кадети прагнули до того, щоб опозиція одержала можливість брати безпосередню участь у справах державного управління. Саме за цю мету й повела свою боротьбу у Лютневій революції кадетська партія на чолі з П. М. Мілюковим. Досягти іï останній прагнув не за допомогою революційної боротьби, а тим паче збройного повстання, а лише законним, парламентським шляхом. 
Головним для П. М. Мілюкова та інших кадетських лідерів відразу після Лютого 1917 р. стало вирішення наступних завдань: створити та організувати діяльність нової влади, покласти край виступам народу і відновити порядок у столиці14. При цьому вони прагнули чинити на маси певний вплив, забезпечити підтримку армії й всіма силами намагалися уникнути громадянської війни. Все це можна було здійснити лише шляхом термінового проведення низки реформ для подолання політичної та економічної кризи в Росії.

Водночас П. М. Мілюков зрозумів, що для оволодіння революційною ситуацією з метою здійснення своїх програмних настанов необхідно мати значну підтримку в армії. Багато кадетів під час Лютневої революції проводили численні мітинги перед військовими. Сам П. М. Мілюков протягом 28 лютого неодноразово виступав у різних частинах, закликаючи солдатів «зберегти єднання з офіцерством, без якого вони перетворяться на пилюку», «знайти своїх офіцерів і чекати наказів Тимчасового комітету», «спокійно розійтися по казармам». Солдатам Гренадерського батальйону він того ж дня заявив: потрібно підкорятися Тимчасовому комітету членів Державної Думи й «ніякої іншої влади, тому що двовладдя небезпечно й загрожує нам анархією та роздробленням сил» ${ }^{15}$. Це означало, що кадети із самого початку революції не прагнули ні з ким ділити владу. Вони намагалися зосередити iї в руках Тимчасового комітету Державної Думи, де, крім них, були близькі їм за духом політики, які поділяли ліберально-еволюційну концепцію подальшого розвитку Росії.

Входження соціаліста О. Ф. Керенського до складу членів Комітету розглядалося кадетами як можливість продемонструвати суспільству свій демократизм і мати прямий контакт з Виконавчим комітетом Петроградської Ради. У цей час розвитку політичних подій лідери столичної Ради вважали: якщо революція буржуазна, то й очолювати іiі повинна буржуазія. Таку позицію поділяв один із їі лідерів В. Суханов, котрий стверджував: «Влада, що йде на зміну самодержавству, повинна бути тільки буржуазною... Таке рішення слід підтримати, інакше переворот не вдасться і революція загине» ${ }^{16}$. Подальший розвиток революційних подій продемонструє помилковість кадетських поглядів стосовно входження соціалістів до складу уряду.

Ліберали на чолі з кадетами хоча й були дещо шоковані розмахом революційного руху, але не відмовилися від наміру зосередити у своїх руках повноту влади та взяти на себе всю відповідальність за долю країни. Обставини складалися так, що ліберали об'єктивно були приречені на керівництво державою. Але з кожним днем розвитку революційної ситуації влада вислизала з рук Тимчасового уряду, і головною причиною цього була діяльність Петроградської Ради. Влада Тимчасового уряду, за деякими параметрами діяльності, мала ознаки безсилля. Ця влада, як говорив П. М. Мілюков, не мала звичного для народу «символу» ${ }^{17}$. Вона підкорялася тиску Петроградської Ради, котра систематично створювала перепони і паралізувала діяльність уряду ${ }^{18}$.

Насправді подальша доля царату не цікавила більшість російського суспільства. Кадети зіграли важливу роль у формуванні серед населення думки, відповідно до якої проведення необхідних реформ можливо лише за умов обмеження самодержавства, що необмежена монархія $\epsilon$ перешкодою на шляху прогресивного розвитку Росії. Всього цього, як вважав Мілюков, можна досягти встановленням конституційної монархії на зразок Англії. Ось чому лідер кадетської партії так наполегливо вмовляв Великого князя Михайла; Олександровича прийняти владу ${ }^{19}$.

Деякі дослідники наводять факти, що Мілюков навіть запропонував Михайлові коронуватися у Москві і звідти розпочати боротьбу за конституційну монархію. Але це лише припущення. Мілюков чітко розумів, що задля цього була потрібна військова сила, якої на той час не існувало. Крім того, Мілюков вважав такий сценарій не найкращим, оскільки він призвів би до початку громадянської війни. Він лише пропонував Михайлові погодитись на можливість прийняти корону, якщо Установчі Збори Росії визначать за потрібне таку форму правління, як конституційна монархія на зразок Великої Британії.

Відразу ж після Лютневої революції ЦК кадетської партії звернувся до громадян Росії із закликом до єдності: «Нехай у загальному пориві забудуться старі пережитки й нехай ніколи вони не воскреснуть знову, нехай Батьківщина вийде з важких випробувань щасливою, вільною, об'єднаною любов'ю та загальним братерством» ${ }^{20}$.

5 березня 1917 р. у редакційній статті газети «Речь» «Народно-російська революція» П. М. Мілюков таким чином охарактеризував Лютневу революцію: «Бували революції 
буржуазні, бували й пролетарські. Але революції національної у такому широкому сенсі, як нинішня російська, досі не було у світі. Усі брали участь у цій революції - і пролетаріат, і військо (більшість якого складали селяни), і буржуазія, навіть частина дворянства, взагалі майже всі суспільні сили країни. А тому ніхто не має на неї виключного права... Усі захотіли, перш за все, бути росіянами, а потім уже представниками своїх класів. Тільки б це об'єднання збереглося до того великого дня, коли обрані загальним, таємним та рівним голосуванням Установчі збори об'єднають весь народ і ухвалять загальне національне рішення, що покладе кінець класовим суперечкам. Нехай до того часу вони замовкнуть» ${ }^{21}$. Ми бачимо, що Мілюков в цей важкий для країни час послідовно проводив ідею позакласової партії, ідею класового миру. Кадети мали рацію, що російській Лютневій революції 1917 р. притаманні суттєві особливості, які відрізняли іії від попередніх революцій. Якщо у революціях кінця XVIII - першої половини XIX ст. в Західній Європі головною революційною силою справді була буржуазія, то в російській Лютневій революції активну участь брали майже всі верстви населення. У своєму списку кадети правомірно на перше місце ставлять пролетаріат.

3 березня 1917 року було сформовано Тимчасовий уряд, в якому П. М. Мілюков став міністром закордонних справ. Врахували його міжнародний досвід, знання основних європейських мов та гарні стосунки з ліберальними колами провідних країн Європи. Головним завданням на цій посаді Мілюков вважав виконання двох важливих умов для поступу країни: завершення світової війни перемогою Антанти та проведення Установчих зборів, які повинні вирішити подальшу долю Росії та іiї форму правління. Саме така позиція і коштувала йому посади. У квітні 1917 р. він здійснив візит до Європи та підписав ноту МЗС Росії до країн Антанти, де запевняв Велику Британію та Францію у виконанні Петроградом своїх союзницьких зобов'язань та важливість завершення війни перемогою. Ці події призвели до квітневої кризи Тимчасового уряду, наслідком якої й стала відставка міністра закордонних справ.

Проте П. М. Мілюков не полишив політичної діяльності, вважаючи головною загрозою розвитку Росії влітку 1917 року партію більшовиків, діяльність В. І. Леніна та Л. Д. Троцького. На жаль, саме він, як міністр закордонних справ Тимчасового уряду, дозволив більшовикам на чолі з Леніним потрапити із Швейцарії (а Троцькому - із США) до Росії у квітні 1917 p.

Незадовго до жовтневих подій 1917 р. у Петрограді задля організації антибільшовицького руху Мілюков переїхав до Москви, та вже було вкрай пізно щось змінити. Потім він опинився на Дону, брав участь в організації та політичному представництві Добровольчої армії. У червні 1918 року він приїздить до Києві, де співпрацює з урядом Скоропадського. Зрештою, у жовтні 1920 року емігрує до Франції, де і залишається до кінця життя, що тривало до 3 березня 1943 р. Довгий час він був редактором газети «Последние новости», яка стала головним друкованим органом російських емігрантів за кордоном².

Таким чином, дуже важко переоцінити роль П. М. Мілюкова під час Лютневої революції 1917 року в Росії. Не підлягає сумніву той факт, що його постать була у центрі революційних подій як до початку революції, так і після неї. Зазначимо найбільш важливі кроки Мілюкова у руйнації російського самодержавства:

- думська діяльність кадетської фракції та власне ії лідера;

- публіцистична діяльність П. М. Мілюкова та принципова позиція у відносинах з вищими урядовцями й царськими колами, негативне ставлення до монархістів;

- виступ у Думі 1 листопада 1916 року («дурість це - чи зрада»?), котрий значно активізував антиурядовий та антимонархічний рух;

- провідна роль у створенні в межах Державної Думи Прогресивного блоку, фактичним лідером якого він став;

- ініціатива створення Тимчасового комітету Державної Думи, що взяв на себе формування Тимчасового уряду;

- участь у подіях 28 лютого 1917 року, коли завдяки своїм дипломатичним та ораторським здібностям Мілюкову вдалося приборкати виступи військ Петроградського гарнізону.

Кожен політичний діяч не може бути ідеально зразковим та застрахованим від політичних помилок і прорахунків. П. М. Мілюков теж не виняток. Він був заручником свого 
часу, опинившись у центрі дії руйнівних політичних сил, вийти переможцем з яких було практично неможливо. 3 одного боку, Мілюков прагнув проводити таку політику, яка б задовольняла інтереси майже всього народу, шукав підтримку в народних масах, але, 3 іншого боку, він мав реалізовувати свої програмні настанови, рішення яких не завжди задовольняло потреби різних верст населення. Час вимагав від Мілюкова і кадетів бути більш послідовними та рішуче здійснювати свої програмні настанови, котрі не могли однозначно подобатися народу. Кадетам потрібен був час, якого, як показав перебіг революції, у них не було.

${ }^{1}$ Державний архів Російської федерації (далі - ДАРФ). Ф. 579. Оп. 1. Спр. 718, 727, 839, 3514. Особистий фонд П. М. Мілюкова.

${ }^{2}$ Струве П. Б. Идеи и политика в современной России. М.: [Б.и.], 1906. С. 10.

${ }^{3}$ Там само. С. 19.

${ }^{4}$ ДАРФ. Ф. 523. Оп. 3, Спр. 20. Арк. 14. Матеріали Прогресивного блоку.

${ }^{5}$ Милюков П. Н. Воспоминания. М.: Политиздат, 1991. С. 445.

${ }^{6}$ Исторический опит трех российских революций. Кн. 3. Коренной поворот в истории человечества: Великая Октябрьская революция / [Гл. ред.: П. А. Голуб и др.]. М., 1987. С. 164-165.

${ }^{7}$ Милюков П. Н. Воспоминания. М.: Политиздат, 1991. С. 450.

${ }^{8}$ Аврех А. Я. Распад третьеиюньской системы. М.: Наука, 1985. С. 8.

9 Черменский Е. Д. IV Государственная дума и свержение царизма в России. М.: Мысль, 1976. C. 25,26 .

${ }_{10}^{10}$ Милюков П. Н. Воспоминания. М.: Политиздат, 1991. С. 452

${ }^{11}$ ДАРФ. Ф. 523. Оп. 3. Спр. 27. Арк. 12. Матеріали нарад ЦК ПНС з думською фракцією.

${ }^{12}$ Милюков П. Н. Воспоминания. М.: Политиздат, 1991. С. 472.

${ }^{13}$ Там само. С. 483.

${ }^{14}$ ДАРФ. Ф. 523. Спр. 32. Арк. 189. Матеріали нарад ЦК ПНС і фракції ПНС.

${ }^{15}$ Речь. 1917. 28 февраля. «Речь» - щоденна газета, орган ЦК КДП (1906-1917 )

${ }^{16}$ Тыркова-Вильямс A. В. Воспоминания. То, чего больше не будет / Послесл. В. В. Шелохаєва. М.: Слово / Slovo, 1998. С. 299.

${ }_{17}^{17}$ Милюков П. Н. Воспоминания. М.: Политиздат, 1991. С. 459.

${ }^{18}$ Думова Н. Г. Кадетская партия в период первой мировой войны и февральской революции. М.: Наука, 1988. С. 174.

${ }_{19}^{19}$ Милюков П. Н. Воспоминания. М.: Политиздат, 1991. С. 489.

${ }^{20}$ ДАРФ. Ф. 523. Оп. 3. Спр. 839. Арк. 2.

${ }^{21}$ Речь. 1917. 5 марта.

22 Чернявский Г. И., Дубова Л. Л. Милюков. М.: Молодая гвардия, 2015. С. 402-453. 